\title{
原子カの信頼回復とは オンサイトからオフサイトヘ
}

\author{
日本科学技術ジャーナリスト会議会長 小出 重幸
}

福島原発事故の最大の課題に,「原子力」や「科学」に対 する国民の信頼を大きく失墜させたことがある。原子力 の技術的な問題の解決は筋道を立てて進めることができ るが, 社会的信頼の回復は 3 年を経過しても出口が見え ない。信頼はどのように失われたか, なぜ回復できない のか, Public Communication（情報公開と広報＝社会へ のコミュニケーション)という視点から考えたい。

\section{情報開示の失敗とその結果}

2011 年 3 月 11 日の福島第一原子力発電所事故では, 政府, 原子力・電力業界が Public Communicationの重 要性を認識していなかったことに加えて，過酷事故時の 対策が極めて貧弱だったことから，事故情報の社会への 伝達, コミュニケーションが著しく遅れた。端的な例 は, 東京電力と政府が原子炬のメルトダウン (燃料溶融) を認めたのは， 2 か月後の 5 月になってからという状況。 そしてなによりも, 事故の規模, これからどうなるの か, その適切な説明がなく, 社会の混乱は拡大, 原子力 は社会的信頼を失った。

同じ時期，英国政府が取った対応をみれば，目指す方 向が大きく違っていたことがわかる。

事故直後の 3 月 15 日, 当時の英国主席科学顧問, ジョン・ベディントン卿 (Sir John Beddington) は英政 府の合同会議で, 福島原発事故の規模と見通しに関する 発表を行った。

「事故の規模はチェルノブイリ原子力発電所事故(1986 年）に比べて遙かに小さく，放射性物質の上昇も地上 500 メートル程度まで。原子炉サイト内の污染は注意が 必要だが, 日本政府の示す 30 キロの退避圈の外では, 放射線による健康影響を心配する必要はない......」

さらに翌 16 日, 東京・半蔵門の英国大使館で, 彼は ネットTVを通して同じ内容のブリーフィングを行い, 日本政府から情報発信がない中で困惑していた日本国内 の欧米人たちの動摇の解消に，大きな役割を果たした。 この情報は当時, 日本国内のマス・メディアでは伝えら れなかったが, 事故直後にいったん日本を脱出した各国 の大使館関係者, ビジネスマンらは, 英政府発表の後, 次々と日本に帰還している。

\section{信頼失墜の背景}

ベディントン卿の会見で特徵的だったのは，様々な専 門領域にまたがる内容を 1 人で，科学的な裏付けに基づ いて明確に答えていたことだ。そして結果的に，英政府
の発表内容は現実を最も良く反映していた。

この時期，日本の政府，東京電力ではどうであった か。連日会見を開いたものの，一方的な断片情報の投擲 に終始した。事故の本質，見通しが明確に語られること はなく，「受け手の心に届いて初めて意味を持つ」という コミュニケーションの面では, 大きな失敗を繰り返した。

同時に，緊急時迅速放射能影響予測ネットワークシス テムSPEEDI の情報開示が文科省, 経産省などの部局 をたらい回しされ，12 日間も公開されなかったことが 大きい。放射性ヨウ素の半減期という重要な期間, 政府 の住民誘導に活かされることもなく，また，科学的裏付 けの薄弱な同心円状退避指示という混乱の原因にもなっ た。深刻なコミュニケーションの失敗であり, これも政 府, 原子力界, 科学界の信頼失墜を加速した。

では英国はなぜ，そんなに早く事故の予測と判断を発 表できたのだろうか。

\section{最も適切な科学的助言とは}

首席科学顧問は, 緊急科学的助言委員会 (Scientific Advisory Group for Emergencies) を抱えている。同委 員会の主要メンバー，ロビン・グライムズ (Robin Grimes) 英インペリアル・カレッジ・ロンドン教授 (原 子力工学) に当時の状況を尋ねたところ, こう説明が あった。

「福島の原子炬はいずれもトリップ (停止)したという 以外, 日本政府, 東京電力からは何も情報が届かなかっ た。停止後の問題は核燃料の崩壊熱制御ということにな る。これに失敗したらどうなるか？ IAEA など国際機 関が共有しているデータベースを基に，福島原発の各工 ニットの燃料棒のリアルタイムの情報を入手し, 分析, さまざまな事故のシナリオを検討した。その結果を，最 も適切な＜最悪予測＞として発表したのだ......」

その気になれば，日本を含めてどの政府でも判断でき た予測ということになる。

しかし事故 5 日後の発表時に，自信は有ったのかを尋 ねると，「100\%の自信は無いけれど，大事なのは絶対確 実ではなく, most suitable (最適)な科学的助言なのだ。 もし不正確な部分があれば，すぐ訂正して行けば良い じゃないか。オーソリティー(政府・科学界)が決断して まず発表することが大事なのだ」という。

明確なメッセージを社会に発しなければ，科学的な裏 付けのないウワサが飛び散る, 科学者の中にもおかしな 
人はいるから，彼らの発言がネットなどで拡散し，社会 はより混乱する。だからできるだけ早く，科学的判断を 示さなければならない一教授の説明を聞くと，日本は 全く逆方向に進んでしまったことを痛感する。

信頼回復のためのコミュニケーション

英国では, 1990 年ころの狂牛病 (BSE 感染症) 発生時 に，政府と科学界が「人間への感染リスクはない」という 全く誤った発表をして対応を遅らせ，感染者を世界に拡 散，社会の信頼を大きく失墜する経験をしている。英国 議会の前科学顧問，デイヴィッド・コープ(David Cope) 教授は,「この失敗を教訓に，英国では社会と科 学をどう結びうけたらよいか，科学コミュニケーション への取り組みを，20 年間にわたって真剣に進めてきた。 福島事故への対応は，その成果が少しずつ現れ始めたも のだ。今の日本も，当時の英国と全く同じ状況。政府， 科学界，メデイア，市民，それぞれをつなげるコミュニ ケーションの努力なしに，社会の信頼は回復できないと 思う」と指摘する。

残念ながら，日本ではその後も科学への信頼が失墜 し, 原子力技術の評価や放射線健康影響を巡って, 行政 の迷走が繰り返された。

\section{福島への追い打ち被害}

避難・除染ガイドラインを政府は，事故後に年間 $20 \mathrm{mSV}$ と設定したが，1 か月後の 5 月に突然 $1 \mathrm{mSv}$ へ

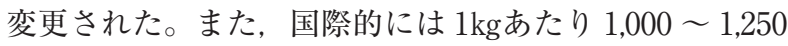
ベクレルが採用される穀物，肉，野菜などの食品放射線 基準を，政府は事故直後，いきなり半分の 500 ベクレル に設定，さらに 1 年後には「安全ではダメ，安心でなけ れば……という厚生労働大臣の指摘で，100 ベクレル へと変更した。

これらの判断には科学的アプローチがなく, 情緒的, 大衆迎合指向で決定されたと指摘されても仕方がない。 これが国内，国外の両面で政府の信頼を失わせた。同時 に, 科学的アプローチを欠いた行為をきちんと批判し, 改善へのメッセージを発しなかった科学界, 原子力界の 信頼も，合わせて失墜する結果となった。

混乱は，被災地・福島に不当な社会差別，心身両面の 健康被害という追い打ちをかけた。

放射線リスクへの冷静な判断が困難になり, 福島の人 たちは大きな心身のストレスにさらされる結果となっ た。南相馬市では, 事故で避難した高齢者の死亡率は, 他の地域の 2.7 倍に達することが東京大学などの調査で 明らかになっている。放射線の被害は，健康被害を心配 する心理的ストレス, 避難に伴う健康リスクなど, 多角 的に評価し、リスクの総体を把握する必要がある。

また，福島県産の農林水産物がすべて放射線の危険性 を抱えている，などの誤解が国内外に広がった。市場流 通を拒否される，価格を買いたたかれるなど，理不尽な 「差別」が社会に拡大してしまった。

\section{科学者, 技術者の責任}

福島事故時，原子力を牽引してきた行政，原子力技術 界, 電力業界, これらの指揮を執る立場にあった責任者 らが，逃げ出す，あるいは当事者能力を失った言動に終 始し，コミュニケーションが成り立たなかった。同時に, 発言すべき時, 行動するべき時に逃走や沈默に終始した 科学者組織，技術者集団にも，批判が向けられている。

混乱の帰着としての信頼失墜とは, 具体的にどんなこ となのか。

さまざまな取材先でいま，原子力が話題になる。日本 のエネルギー安全保障の視点から判断すれば，原子力発 電を利用することは仕方がないと考えている人は, 決し て少なくない。ところが再稼働するにしても，「信用で きないので, あの人たち(今の原子力技術者)には, やっ てもらいたくないね充……——いう反応が極めて多 いのだ。こうした現実を，原子力業界がどこまで受け止 めているのか。

失敗をきちんと総括し，教訓を明確にする，進むべき 方向を示し，イニシャチブを取る—こうした社会への メッセージが求められているが, 現状では,「何の意識 変革も無いまま, なし崩し的に再稼働に向かうのではな いか」と疑う市民が多い。こうしたコミュニケーション 能力を欠いた「原子力の世界」,「あの人たち」に，人々は 信頼をおけないのだ。

専門領域を超えたメッセージ

福島原発事故時に内閣官房参与として官邸で事故対策 に取り組んだ，田坂広志・多摩大学教授は，国民の不信 感は, 原子力行政を仕切ってきた官僚機構, 科学界や技 術者らのすべてを卷きこんだ，巨大なものだと指摘， 「人材, 制度, 組織, 文化——これに明確なヴィジョン が示されない限り，人々の信頼は戻らない」という。

技術者一人ひとりに会えば，誠実に，熱意を持って原 子力に取り組んでいる人材が多いことは, 我われ取材者 にも分かる。問題は，オンサイトの技術的課題より，才 フサイトのコミュニケーションにある。全員とはいわな い。要所できちんとメッセージを投げてくれる科学者, 専門領域に逃げこまず，社会に向けてコミュニケーショ ン力を発揮してくれる技術者が欲しい。英国がこの 20 年続けてきた努力とは, 指導的立場で行動できる科学 者, エンジニアの育成でもあった。

信頼回復には, 行政, 原子力, 電力業界の連携が不可 欠だが，その基盤となるものは科学的アプローチしかな い。まず，専門領域を超えて価值観を示す科学者や技術 者, それを支えて社会にメッセージを発する科学・技術 者集団の育成が急務だと思う。

(2013 年 12 月 12 日 記) 